\title{
A Perception of Cultural Dialogue between the Missionary Enterprise of a Protestant Faith and Benin Indigenous People of Nigeria
}

\author{
Emmanuel Orihentare Eregare (M.A, M.A, Ph.D) \\ School of Education and Humanities, History and International Studies Department, Babcock University, \\ Ilishan-Remo, Ogun State, Nigeria
}

\begin{abstract}
The seeming issue of syncretism between Christianity and African traditions had rarely been viewed from an historical research methodology especially between the Benin people of Nigeria and their declaration for Christianity which needs urgent attention. Hence, this study explores the subject matter through cultural interactions between the contemporary travail of the Seventh-day Adventist missionaries' enterprise and Benin indigenous People. This study employs historical research methods of data collection and collation. Findings reveal that Benin culture impedes the faith of the indigenous people on wholesome biblical faith. This study suggests that it is imperative, among others, for every Christian faith to develop a set of biblical lessons on Bible and traditions as a prerequisite for contemporary Missiological approach and to be studied in various denominations within their host communities to avert the influence of the indigenous traditions over biblical injunctions.
\end{abstract}

Keywords: Culture, Missions, Protestant Faith, Nigeria

DOI: $10.7176 /$ JAAS/57-05

Publication date: August $31^{\text {st }} 2019$

\section{Word count: 138}

\section{Introduction}

The seeming practice of syncretism between Christianity and African traditions had rarely been viewed from an historical research methodology which this paper tried to handle. Syncretism is the amalgamation or attempted amalgamation of different religions, cultures, or schools of thought (Syncretism 2019). African proponents as Madu (2004) claims that syncretism of Christianity and African religious heritage need to cohabit to enable African understand, accept and allow both to live together as a source of commonwealth. This great phenomenon needs urgent clarification as the Eregare (2013) avowed that there should rather be the separation and leaving the uniqueness of each religious existentialism within any given community. This study thus focus on the coming of the Seventh-day Adventist missionaries to Benin as they tried to make converts of the indigenous people and how the issues of differed cultural differences were addressed and established their distinctive positions.

This study, on the other hand, examines the travail between the missionary enterprise of the Seventh-day Adventist faith and the traditions of the Benin people while making disciples. It further records the interreligious cultural impacts between Christianity especially on the Seventh-day Adventist faith and Benin Indigenous peoples' response to Christianity and transformation that proceeded their interactions, challenges and make suggestions. It provided platform for other researchers to engage in this kind of study as they could pick any denomination of their choices and traditions of its host communities in any part of the world through a historical research methodology for critical examinations.

1a. An Insight on the Seventh-day Adventist as a Protestant Faith

The Seventh-day Adventist Church is a distinctive protestant denomination which is committed to communication of the three angels' message as found in Rev. 14: 6-12. It is further explained as

The Seventh-day Adventist Church Christian denomination which is distinguished by its observance of Saturday, the seventh day of the week in Christian and Jewish calendars, as the Sabbath, and its emphasis on the imminent Second Coming (advent) of Jesus Christ (Wilson 2019; Seventh-day Adventist Church (July 2019).

1b. A History Geography and Civilization of the Benin People

The great Benin Empire was established 2300yrs before any contact was made with European nation (Great Benin Empire 2016). It would not be, therefore, adequate for any scholar to opine that such great lived city had been a dark nation without some levels development nor civilization though the Binis were described as an inferior nation. Osagie (2016) argues that it could only be said that the Europeans were much advance in certain area of life than the Benin people. It is believed that the Benin people have possessed over the years some levels of civilization as well.

Connah (1975) postulates that Benin Empire is located in a plain divided by rivers, surrounded by a rain forest. Evidences narrated that the Benin Empire was made up of the Edo-speaking peoples which include the 
Edo, Ishan, Etsako, Ivbiosakon, Akoko Edo, Ineme, Urhobo, and Isoko. The Empire, in the $15^{\text {th }}$ century, had an overwhelming power over her neighbouring peoples as the western Igbo, northeastern Yoruba and so on.

There are three common views on the origin of the Benin people. Firstly, the origin of the Benin people has been a discourse among the scholars over the centuries. History recorded that the Benin People can be traced to Egypt. Secondly, another oral history postulated that the Benin people actually originated from Ile-Ife though once claimed to have been sheltered by the Sudanese. Thirdly, oral history narrated that the Benin people migrated from Sudan or Nupe to settle in Benin before the coming of the Ile-Ife contingents (Osagie 2016).

In a political sense, the Benin people were conscious of their robust and well organized government, administration of law, system of landholding, farming and festivities (Mbiti 1969). Egharevba (1968) adds that the ancient Benin people practiced dynasty system under the rulership of 'Ogiso' dynasty in 900 A.D. The arrival of another king called Odudua from Ile-Ife around $12^{\text {th }}$ century. The first ruler became so famous for his love for peace and gift of organization. Ere was said to have founded many villages or settlements as Ego and Erua. Ryder (1980) narrates that several other rulers that govern the people brought values to the development of the Benin culture. According to archaeological investigation, Connah hypothesized that the Edo-speaking people must have lived together under a political umbrella until she was conquered by the British colonial forces and was made to be part of the Niger Protectorate in 1897. In addition to the conquest of the empire, Ryder states that Benin Kingdom was made an independent state in 1897 (Connah 1975). However, Oral tradition has it that the Benin Empire made remarkable achievements in art, science, administration, technology, political organization, architecture, astronomy, town-planning and so on during the ancient times. These areas of societal developments showed the level of their growth into civilization (Great Benin Empire 2016).

1c. An Insight on Benin People and their Religious Affinity

In Mbiti's work, African especially the Benin people were religious and had a religious descent. The Benin have a traditional religious culture with a set of religious values and practices. The Benin traditional religion is palpable in every area of her culture. The Benin people have been religiously inclined before, during and after the visit of the Europeans (Mbiti 1969).

Every Benin man was conscious of his homeland, work and could regulate his daily life based on her valued beliefs and taboos. The coming of Christianity, European institutions and ways of life, however, posed challenges which were to be inculturated into the Benin people's beliefs and cultural framework during their missionary enterprise. This venture met with a halt or made the potential indigenous people who desired to be Christians to either choose to be Christian or remain in their traditional religion which was not an easy task for a common Benin man to decide nor was it easy to Christian and abandon some of her traditional practices (Osagie 2016).

\section{A Historical Development of Christian Missionary Enterprise and Benin Peoples}

In no doubt, the coming of Christianity had added significant values to Benin nation in areas of development or civilization. The coming of the Europeans in $16^{\text {th }}$ century was another indispensable factor that boosted the economy and stability of Benin Kingdom. According to oral tradition, brass trade flourished at the coming of the Portuguese which increased their fame national and internationally. The trade was controlled by the Oba and chiefs. They enjoyed the monopoly of many of the products such as pepper and ivory. The $17^{\text {th }}$ century brought a great expansion of the European trade as Dutch and English merchants competed fiercely for Benin's ivory and cloth. These transactions brought Benin Kingdom into international relations with the outside world selling their culture and attracting other business international partners (Ryder 1980).

Uka (2005) argues, however, that the advent of Christianity to Benin, by the Europeans, was not only tagged with a positive connotation, it was as well viewed as coming “... to save Africans from being Africans as if being in themselves was the greatest sin. In their scheme of salvation, no distinction was made between sin and African customs" The implication was that the coming of the Europeans was to avert the continuity in her traditional beliefs and practices and impose the European culture over hers.

Further, the fifteenth century ushered in the sea route discovery by the Portuguese to Africa under the leadership of Prince Henry the Navigator. The Navigation unveiled the existence of people who had never being evangelized beyond the Sahara desert (Kwiyani 2004). According to the Papal Act of 1493, the Portuguese came for missionary work along the West African coast and with other motives of seeking gold and slaves (Isichei 1995).

In the sub-Sahara, the missionary efforts was established in Benin City. Early scholars rather claimed that the primary aim of the Europeans to Benin Kingdom was for trade or economic reason. C.M. Sorgwe admitted that "although the Portuguese primary objective was trade, no efforts were spared pursuing the noble idea of converting the inhabitants to the Christian religion. They had hope to convert the people and make them allies of Christian Europe against Muslims" (Sorgwe 1997).

Sorgwe (1997) notes further that the Italian Capuchin mission in Sao Tome brought Christianity to Warri and Benin respectively in the $15^{\text {th }}$ century. Oba Orogbua, the ruler as at the coming of Christianity welcomed the 
religion and built some churches in Benin. Okao (2016) rather argues that oral tradition revealed that Christianity came to Benin in 1509 ( $16^{\text {th }}$ century) during the reign of Oba Esigie. Christianity could not survive at the first contact with the Benin people. So the religion was taken to Warri. Esigie who was the Olu of Benin as at the $16^{\text {th }}$ century Christianity came to Warri. Warri people welcomed Christianity and even sent his son, Eyeomasan to Angola in pursuit of Christian Education. In the $17^{\text {th }}$, Christianity flourished in Warri, the then part of Benin.

\section{Christianity and Benin Traditional Religion: An Inter-cultural Insight}

From the onset of Christianity in Benin, it was narrated to have flourished greatly as it brought development to the old Benin Kingdom though the human general development aspect was confined to the Royal Court. The essence of this latter was because of the educational institution Christianity brought for the indigenes on how to read and write. The Royal office decided to make it an institution of the upper class within the Royal Court. The Portuguese, therefore, patterned Christianity side by side with their culture as a way of life for the people in Benin Kingdom. This began the inculturation process of the European of their religion to her host community. The Portuguese also placed Christianity above the African Traditional Religion. This was the issue that generated the struggle of the European culture over the Benin traditional practices. The dilemma it eventually created between the early Christian missionary and the Benin people can, thus, be explained as:

The fortune of Christianity in West Africa (Benin) depended to a large extent on syncretic or receptive quality of older West African religions. The culture of West Africa also displayed great variety, ranging from elaborate political system to a small village Kingdom, and polygamy which was recognized in West Africa as a way of life but was alien and unacceptable to the Portuguese (Sorgwe 1997).

The magnitude of the inter-cultural integration was designated to make converts from the host religion to Christianity. This task was underestimated by the Europeans. Neither could the Europeans understood the extent of travail their decision would cause in the process of integrating her culture into Benin community. The Europeans seemed not to have considered that the religion they were introducing to Benin people was culturally different from that which Benin people were used to and had developed. This is further explained, as cited in Eregare (2013), as:

When trade formed the basis of contacts between two cultures, conflict was less frequent than when contact was extended to the sphere of religion which usually resulted in clash of fundamental values. The launched assaults upon customs and beliefs which they found objectionable thereby caused conflict and alienated the majority of the people they had come to convert. Attacks on polygamy, human sacrifices, the destruction of images and shrines often preceded conversion instead of following it.

From the foregoing, Benin became the first place Christianity was established in the Sub-Sahara part of Africa in 1509. The Portuguese located the first place of worship where the present Holy Aruosa Cathedral is situated in Benin City. History postulated that the search for this suitable venue was a venture with so much difficulties. Three places were initially earmarked and considered. But the present place where The Holy Aruosa Cathedral is located was claimed to be the most suitable in agreement with the Portuguese. Oral history had it that the Europeans use the venue for their worship and the worship was based on their traditional way of worshiping God. This attempt showed the basis for growth in European culture which were confronted by the Binis (Okao 2016). This intentional imposition of European was a serious threat to erode intentionally Benin culture completely. The Benin people arose to their communal spirit to bring continuity to the worship of God in their traditional approach and not in European ways.

The Benin people converted the church to their traditional church where they were able to corroborate their cultural values as polygamy, African traditional approach to worship and religious ways of life (serve God and not Jesus which they knew before the introduction of Christ by the coming of the Europeans) and ideas etcetera. Based on this latter assertion, they were known as Godians and not Christians. The first Christian church established by the Europeans was converted to Holy Aruosa Cathedral where the belief of Benin people have been held with high esteem and to serve God alone. The Holy Scripture was replaced by The Holy Aruosa Cathedral holy book is The Book of Holy Aruosa: Teachings and the Sayings of Benin. The Book of Holy Aruosa: Teachings and the Sayings of Benin became the source of book that prescribes her teachings and way of life of her people.

Oral history affirmed that the Book of Holy Aruosa is a book that should never be compared or weighed with the other holy books of any other religions as the Bible or Qur'an. This latter assertion is without the exemption that other Holy Books should be neglected. The members of Holy Aruosa could as well read any other Holy Books if they desired. The Holy Aruosa became traditionally the primary place of worship for the indigenous people, Royal House and the Oba as the head of the church (Okao 2016).

Unclear to the Benin traditional religion, Elmer (1993) argues that the conceptualization of God and His son, Jesus Christ is transcultural which made it expedient for a general acceptance without reservation. God in Christian perspective is a God of diversity who sent His Son to redeem and get humanity adopted as His sons and daughters. Elmer asserted that it is in Christ Jesus that salvation of humanity lies which the Benin Godian 
religious practice subscribes to partially without Christ Jesus at the center at all.

\section{Seventh-day Adventist Missionary Enterprise and Benin Traditions: An Inter-cultural Insight}

Before the coming of the Seventh-day Adventists' missionary enterprise, the Western region mission of the church from Ibadan had a department of Voice of Prophecy (VOP). Further, oral history recorded had it that this department had been in the business of sending some of the materials containing their core messages on the three angels' message and some of the indigenous people were responding positively to them. The responses and the decision of a few of the Benin indigenes who indicated for baptisms necessitated the need to send the first official missionaries to the region. Hence, it was recorded that S.A Majolagbe and J.O Eregare were officially sent though one before the other to search for the baptismal candidates and baptized them, therefore, establishing a church over four centuries of the Christianity's presence in Benin environ (Eregare 2013).

However, another historical account revealed that there was also a lone squad, Literature Evangelist, who probably worked alongside the VOP ministry who had vigorously shared literatures containing some of the doctrines of the church to the people in Benin called Onamadu (Eregare 2013).

These twin efforts actually prepared the in-roads to evangelize the Benin people through missionary enterprise. The voice of prophecy approach was opined to have probably recorded more success that of the Literature Evangelist in establishing a branch Sabbath School. The church was established in 1948 (Eregare 2013).

The Benin community was believe to be bastion and citadel of culture in Nigeria. Since the arrival of Christianity, they enjoy living double-standards. They got converted into Christianity yet held tenaciously to their traditional practices. They worship God yet practiced their traditional beliefs as attending to festivals. They were found eating all kinds of unclean meats as crayfish, crabs, snakes and the like which the Seventh-day Adventists classified as unclean as stated in Leviticus $11 \& 14$ respectively. They were used to wearing beads and other jewelries which the church condemns as outwards adornments were inimical to biblical teachings. The Benin men loved polygamous practice which the Seventh-day Adventist missionary frowned at as not biblical. These, among others, the missionary were rigid in the application of the believes and practices of the church, These approaches of applying the Bible and Bible alone and the idea of not giving a window to the new converts to practice all the traditions that were not biblical was the foundation of the conservatism that are still being practiced by the contemporary Seventh-day Adventists in the present Edo and Delta states. Nevertheless, the Seventh-day Adventists teach their beliefs from the Bible and Bible alone as the source of her faith and practice (Eregare 2012).

The early missionaries' holistic approach to reach the indigenous people with the Gospel of Jesus Christ was through rich Bible study and inculcation of the practices therein. They practiced them and made disciples of the converts. The prospects or newly converted members were rigorously taken through the basic fundamental teachings of the church and, in turn, make decisions to be members (Eregare 2013).

\section{An Insight on Seventh-day Adventist Beliefs and Benin Traditional Practices: A Comparative Analysis}

This study discovered that though the arrival of Christianity succeeded and grew geometrical but without a wind of great challenges. The Benin people rebelled against the teachings and practices of Christianity. It appeared to them as if there culture had been eroded by the Europeans which cherished dearly. Thereby, the Benin people probably in counsel took a decision to return back to her traditional practice and serving God in an African approach. Christianity denied them of their most cherished culture such as polygamy and the like.

The Benin Royal Court and people got back the place initially giving to the Europeans to establish as a place of worship. They changed the concept of being Christians to Godians. They hence declared that they did not believe in serving Christ but God. The Oba is the priest of their Cathedral where they worship God. The Godians believe in God and the laws.

The laws they believe in are slightly different from the Ten Commandments as it is in the Bible. Secondly, they believe in no deities or Jesus or any form of intermediaries to God. While Christians believe in God, Jesus and the Holy Spirit, the Trinity as the Godhead, Godians believe in God alone. Christians pray in Jesus name, Godians pray directly to God in heaven. The High priest serves as a coordinator in all that has to do with the worship of God. Christians and Godians believe in marriage. Godians believe that a man can marry as many wives as long as he will cater for their needs. If a man marries one or two wives as the case maybe without being able to cater for their needs, Godians believe that it is a sin. The Godians believe and practice culture while they submitted that they rejected the practice of idolatry. Eregare (2019) submits that the Seventh-day Adventist uphold one man one wife as established and ordained by God.

The basis as well for the enterprise, her beliefs, and Missiological challenges and growth in the present Benin territory from the twentieth century, precisely in 1948-2018. The Seventh-day Adventist faith came to Benin in 1948 which was about five centuries after the first set of European Christian missionaries. By this period, the Benin people had undergone various developmental stages and possess a cross-breed of civilization. 
The average Benin man could read and write. The mid-twentieth century was characterized with the Christian missionary evangelization through mails and other present Missiological approaches to evangelism. The Missiological approach used by the Seventh-day Adventist to reach Benin people was through mailing of Bible correspondent course tagged 'Voice of Prophecy Study'. The question and answer study material were administered to people who were willing to understand the Bible. The institute of the Voice of Prophecy in the Seventh-day Adventist church served as a powerful tool for missionary enterprise around this era. After the study certificates were issued usually to correspondents who completed the lessons successfully. Those who at the end wish to join the church were sought for and thereby the first church was organized (Eregare 2013).

The Benin people at the coming of the Seventh-day Adventist were both Christians and pagan. Some rather practice both religions-dual allegiance. Eregare (2012) unveils that when he said

The average Edo person has double allegiance. They mix Christianity with traditional religion. They have multi beliefs in the deity and divinity. They are pagan inclined in culture. The Edo people are generally materialistic which affects their commitment to Christianity. They live more in fear than in faith. They believe in the ancestral worship

- worshiping, the spirit of the dead.

The Christian churches present at the coming of the Seventh-day Adventist then were, the Roman Catholic, Anglican, Methodist, Baptist, Cherubim and Seraphim.

The Benin believe in only one God. At the same time, they believe that God is as well believed to have children who were his deities. For example, the deities were Olokun, Ogun, Orunmila, Okhuahe and Igue. The issue of polygamy use of kola nut for various ceremonies and consumptions, wearing of beads, Saturday market days and farm days were common phenomena and factors that challenged the missionaries of the Seventh-day Adventist (Eregare 2012). The Seventh-day Adventist upholds the biblical teaching and healthy life style that prohibit her adherents from the consumption harmful substances and unbiblical practices such as the consumption of kola nut as opposed to a healthy life style, wearing of beads which was part of the identity of the Benin people, polygamy and Sabbath (Saturday worship) which is opposed to the biblical monogamy. The idea of separating her cherished festivals for Christianity and the pre-existing churches were, among others challenged the Seventh-day Adventist missionaries. The Benin people with their idea of dual allegiance to religiosity can be viewed from the angle of the Hebrews that were addressed and not willing to be committed to avoid the thought of "whether they had made a mistake leaving the traditions of their families, friends and ancestors to embrace Jesus Christ. Edo (2016) added that, among others, the influx of Pentecostalism, Sabbath keeping were the key challenges faced by the Benin indigenes becoming Seventh-day Adventists.

\section{Conclusion}

This study mirrors a dialogue between the Seventh-day Adventist missionary enterprise and the Benin culture. Findings revealed that the culture of the Benin people impedes the indigenous people who have professed publicly as Christians to anchor their faith on the biblical truth alone without mixing their Christianity with their cultural beliefs. They pay allegiance to their traditional inherited practices and claim to be Christians as well. They find it difficult to separate from their traditional cultural practices. Even though the difficulty is present till today, the Seventh-day Adventist missionaries were able to establish her faith in Benin City through undaunted facet of challenges. There appeared to be a stampede of culture to uphold the other. Findings reveal further that the indigenous people that could not adhere completely on biblical injunctions which supersedes human culture, especially the ones that were inimical to the biblical injunctions, were able to develop their church. They thus worship on Sunday as opposed to the biblical injunction of Sabbath as practiced by the Seventh-day Adventists (Exodus 20:8-10). The Binis called their faith Godians as in variance with Christianity. This work submits the Seventh-day Adventist established her missionary enterprise that upholds biblical injunctions without equating it with traditions or weigh it side by side. The tradition of bible alone as the sole interpreter of itself must be upheld to be a faithful adherent of her faith.

This discourse thus suggest that if God is the author of culture, Christians (Seventh-day Adventists) should ensure that there should be a constant education through seminars, lectures and so on to separate the biblical culture from the human made culture as Benin traditional culture using biblical evidences to supports her claims and the danger in dual allegiance in Christianity.

If the Seventh-day Adventist faith and practices are in conflicts with the Benin Traditional values, it behooves on the S.D.A. Church to inculcate the comparative teaching that will separate the two institutional values as topic to be discuss during their evangelistic series or for nurturing her members after conversion. This will, in turn, aim at strengthening the faith of the Seventh-day Adventists and the prospective members to avoid especially the few practices of the Benin traditional values that are inimical to the Biblical injunctions.

If, In turn, the values of the African Benin Traditional culture especially on religion must be projected and preserved, her adherents should be taught too in there traditionalized churches for them to curb syncretism of both religion or choose one. 
With the above findings through historical research methodology in examining the issue of syncretism of Christianity and African Traditional beliefs and practice, Christian denominations other than the Seventh-day Adventist Church can borrow a leave to enable examine, establish findings which will enable preserve biblical culture above human culture when and where clashes exists.

\section{References}

Connah, G. (1975). The archeology of Benin, Oxford: Clarendon.

Edo, J. (September 8, 2016), Oral Communication with the author. (A Minister of the Seventh-day Adventist Church, Benin City, Edo State. C. 45years).

Egharevba, J.A. (1968). Short history of Benin, Ibadan: Ibadan University Press.

Elmer, D. (1993). Cross-cultural conflict: Building relationships for effective ministry, Illinois: Intervarsity.

Eregare, E.O. (2013). An African Christian Church history: Seventh-day Adventist cosmology in Edo/Delta states: 1948-2012, Lagos: Christ Coming Books.

Eregare, E.O. (September, 2012). 'The Growth of the Seventh-day Adventist Church in Edo-Delta Field: 19482012" PhD dissertation, Nnamdi Azikiwe University, Awka, Anambra State.

Eregare, E.O. (2019). Managing Couples' Conflicts: From Conflict Creators to Conflict Transformers, Lagos: Freedom Press

Ezeogu, E. (1993). "Bible and Culture in African Christianity" Rudi Maier (compiler) in Theology in Context of Africa: Cultural and Religious Analysis, Lagos: Babcock University.

Kwiyani, H. (2004) "The mission of God belongs to Africa too: The emerging story of the African missionary movement”, Journal of Contemporary Christian Studies (01) 01,

Isichei, E. (1995). A history of Christianity in Africa: From antiquity to the present, Grand Rapids: Eerdmans.

Madu, J.E. (2004). Honest to African Cultural Heritage, Onitsha: Coskan.

Mbiti, J. (1969). African religion and philosophy, Ibadan: Heinemann.

Okao, H. (August 14, 2016), Oral Communication with the Author, Benin City, Edo State. C. 50years).

Osagie, E. (September 1, 2016). Benin in contemporary Nigeria: An Agenda for the twenty-first century, (http://www.dawodu.net/osagie.htm

Rodney, W. (1992). How Europe underdeveloped Africa. London: Bogle-lo'uverture.

Ryder, A.F.C. (1980). "The Benin Kingdom" in Obaro Ikime (ed.), Groundwork of Nigerian history, Ibadan: Historical Society of Nigeria.

Seventh-day Adventist Church (2019), https://en.wikipedia.org/wiki/Seventh-day_Adventist_Church

Sorgwe, C.M. (1997). A textbook of Niger Delta, from the earliest times to the present. Ibadan: Rescue.

Syncretism (July 21 2019), https://www.google.com/search?client=firefox-b-d\&q=what+is+sycretism.

The great Bini Empire: An African legacy (June 24 $4^{\text {th }}, 2016$ ), http <//www.africaresource.com/rasta/sesostris-thegreat-the Egyptian-hercules/the-great-bini-empire-african-legacy $>$

Uka, E.M. (2005). Issues in Theology, mission, church and society, Calabar: Clear-lines.

Wilson, T. N, (July 20 2019), Why did Seventh-day Adventist separate from Protestants and Worships on Saturday? https://perspectives.adventist.org/en/questions answers/questions/go/2018-0406/why-did-adventists-separate-from-protestants-and-worship-on-saturday/ 